\title{
Experimental research of equipment for burying in the ground the drip irrigation lines
}

\author{
Dragoș Manea ${ }^{1, *}$, Eugen Marin ${ }^{1}$, Gabriel Gheorghe ${ }^{1}$, Cătălin Persu ${ }^{1}$, and Roxana Mitroi ${ }^{2}$ \\ ${ }^{1}$ National Institute of Research - Development for Machines and Installations designed to Agriculture \\ and Food Industry - INMA, Bucharest 013813, Romania \\ ${ }^{2}$ University Politehnica of Bucharest, Faculty of Biotechnical Systems Engineering, 313 Splaiul \\ Independenței, 060042, sector 6, Bucharest, Romania
}

\begin{abstract}
The equipment for burying in the ground the drip irrigation lines was designed and built at INMA Bucharest, within a complex research project carried out in partnership with other institutes, universities and research stations in Romania. The equipment is intended for drip irrigation technology for field crops. Subsurface crop irrigation technology is a variant of the classic drip irrigation technology, in which the drip lines are buried below the soil surface, providing water directly to the root zone of the plants. The depth of burial and the distance between the drip lines depends on the type of soil and the structure of the roots of the crop. The activities prior to the experimental research consisted in determining the characteristics of the test field (soil compactness, soil moisture, geographical coordinates of location). Experimental research of the equipment aimed at determining the energy indices (working speed, traction force, traction power, working capacity and fuel consumption).
\end{abstract}

\section{Introduction}

Subsurface crop irrigation technology is a variant of classical drip irrigation technology, in which drip lines are buried below the soil surface, providing water and / or fertilizer directly to the plant root zone. Compared to surface drip irrigation, subsurface irrigation technology has the following advantages: it eliminates surface evaporation; reduces water stress of the crop; prevents weed germination and reduces the use of herbicides; reduces the need for labour; reduces maintenance costs and ensures the safe and efficient delivery of fertilizers.

The equipment for burying pipes for subsurface drip irrigation is composed of a towed frame on which are mounted drums with tubes in the form of a coil which run through a section for burying in the soil at different depths.

There are relatively little research in the literature on equipments for burying drip irrigation lines in the ground. It is known from the prior art document [1], where the gutter opening organs are simultaneously assisted by other organs, which, as the irrigation tube is unrolled, cover the ditch with the soil resulting from the excavation.

Internationally, various equipments are being built for the placement of irrigation hoses in the ground, manufactured by prestigious companies [2, 3, 4]. Compared, these equipments differ from each other by the width and depth of work, the number and construction of the working organs, the power of the tractor with which they are intended to work in the aggregate, etc. Instead, the technology of subsurface drip irrigation has been studied over time by several researchers [5 - 8].

\footnotetext{
*Corresponding author: manea_dragos_05@yahoo.com
} 
Subsurface drip irrigation gives higher crop yield compared to surface drip irrigation [9], it can reduce the environmental risks and decrease nitrate leaching rates [10], but it has the disadvantage that it is very dificult to observe when a transmitter gets clogged [11].

Within a complex project developed in partnership with other research institutes, public universities and research resorts in Romania, INMA Bucharest designed and built equipment for burying drip irrigation hoses in the ground (fig. 1), intended for agricultural farms who want to implement the technology of subsurface irrigation of hoeing plants or vegetable crops, in the open field. This equipment works in aggregate with wheeled agricultural tractors, provided with suspension mechanisms in three points category III according to ISO 730: 2012. The equipment is of the type carried on the hydraulic lift of the tractor, it has two working elements of vertical blade type and chisel knife, the distance between the organs being adjustable in the interval 70-140 cm and the working depth being between 15 and $45 \mathrm{~cm}$.

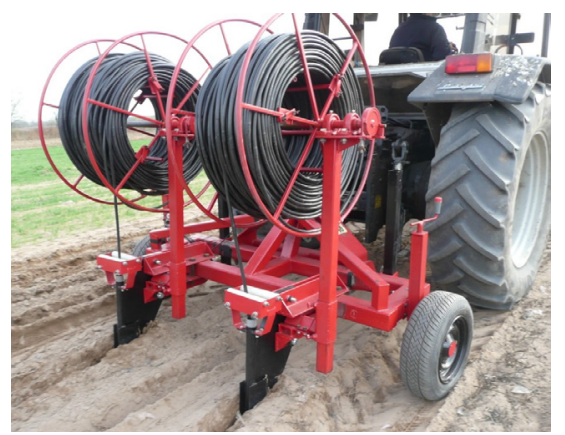

Fig. 1. The research object: equipment for burying drip irrigation lines in the ground

This paper presents the results of experimental research on the equipment for burying drip irrigation lines in the ground, research that aimed to determine energy indices (working speed, traction force, traction power, working capacity, fuel consumption), in the conditions of an arid area in Romania and a sandy soil.

\section{Material and method}

The experiments of the technical equipment for burying drip irrigation lines in the ground were carried out within the Testing Department of INMA Bucharest and in the experimental plot of SCDCPN Dăbuleni, during October - November 2020. The experimental research was carried out in several stages.

In the first stage, in the most critical points on the equipment were glued with special adhesives tensometric marks KYOWA model KFSG-6-120-C1-11N15C2, $120 \Omega$, temperature coefficient $11 \mathrm{ppm} /{ }^{\circ} \mathrm{C}$, which measures the components force parallel to the direction of movement of the equipment and perpendicular to this direction (Fig. 2).
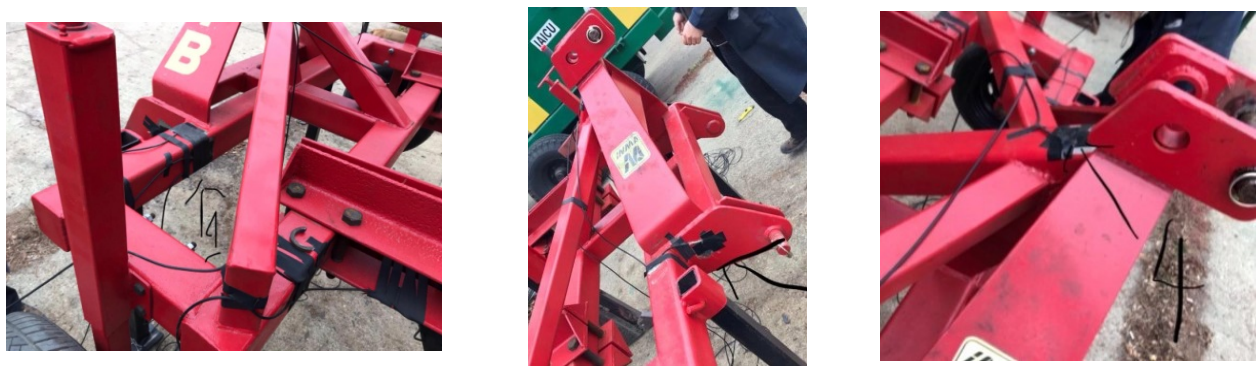

Fig. 2. Tensometric marks glued to critical points on the equipment frame 
The next step was to assemble the equipment on the experimental laboratory stand and calibrate the tensometric marks (Fig. 3). The equipment used consisted of: Hydropuls installation (hydraulic actuator; load cell 10 - $100 \mathrm{kN}$, Type FC-10, series 8608, with reading on the deck SERIES $366.90 / 87 / 13 / 1987$, measurement uncertainty $0.89 \%$ ), laptop with specialized software package; QuantumX 1615 data acquisition system, 2 modules with 32 measurement channels each module.

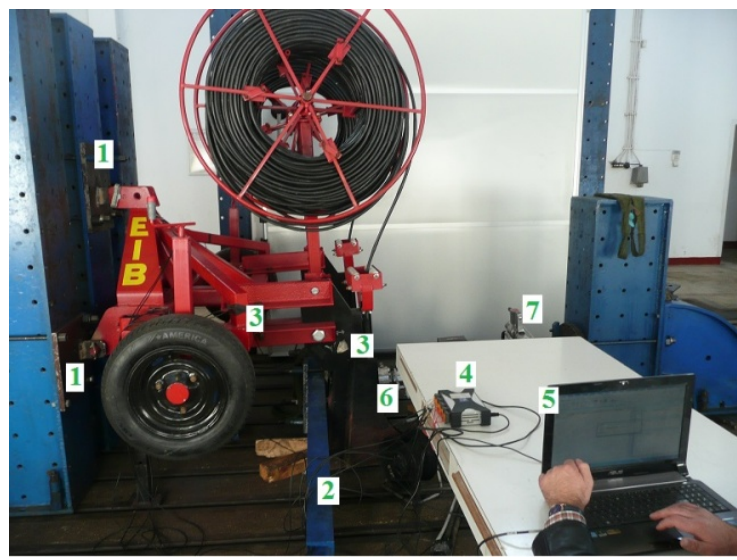

Fig. 3. Experimental stand for calibration of tensometric marks in the laboratory: 1 - fixing elements on the stand of the equipment; 2 - drawbar; 3 - tensometric marks glued in the critical points; 4 - data acquisition system; 5 - laptop; 6 - hydraulic actuator; 7 - load cell

The third step was to determine the characteristics of the test plot (Fig. 4). The soil of the experimental polygon of SCDCPN Dabuleni is a sandy soil, poorly developed (psamosol), with a coarse sandy texture (74-84\% coarse sand), contains little clay $(0.7-3 \%)$ and dust $(2-4 \%)$.

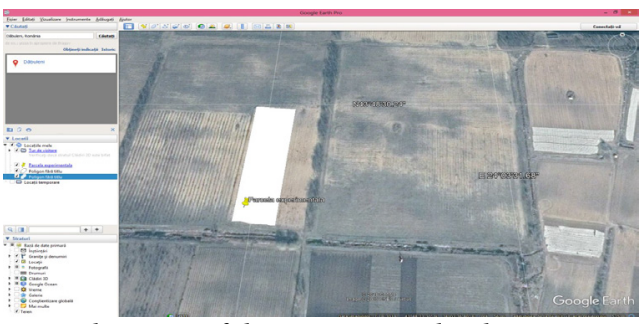

location of the experimental polygon

(geographical coordinates: $N 43^{\circ} 48^{\prime} 30.24^{\prime \prime}, E$ $\left.24^{\circ} 0.3^{\prime} 5.76^{\prime \prime}\right)$

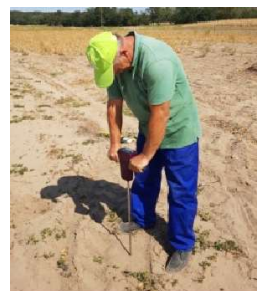

measuring soil compactness

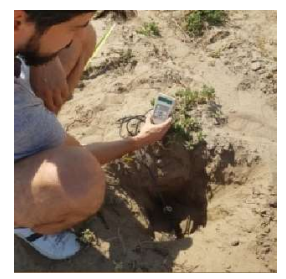

soil moisture measurement

Fig. 4. Aspects during the determination of the characteristics of the test plot

The FIELDSCOUT SC 900 digital cone penetrometer was used to measure the compactness of the soil. The measurements were performed at five points located on the diagonal of the experimental polygon. The average value of the resistance forces to the penetration of the cone in the soil layers in the depth range $0 \div 40 \mathrm{~cm}$ is $4694 \mathrm{kPa}$, which means that the soil falls in the middle class of compaction. Soil moisture was measured with the Delta - T Devices portable humid - meter, model HH2 with Theta Probe ML2x probe, at the same points where the compactness was measured and on the same depth range. The average value of soil moisture at a depth of about $20 \mathrm{~cm}$ was $6.5 \%$, and at a depth of about $40 \mathrm{~cm}$ it was $16.8 \%$. 
Subsequently, the traction force was measured in the experimental plot from SCDCPN Dăbuleni (Fig. 5). The traction force was determined by the tensometric method, which consists in the direct measurement of the forces that appear in the structure of the equipment frame. The traction force of the equipment is the algebraic sum of the components of the force parallel to the direction of travel. The tractor used was Lamborghini with a power of $150 \mathrm{HP}$. The measurements were performed at two working depths, $20 \mathrm{~cm}$ and $40 \mathrm{~cm}$, for three working speeds $(2.46 \mathrm{~km} / \mathrm{h} ; 3.30 \mathrm{~km} / \mathrm{h}$ and $4.50 \mathrm{~km} /$ h).

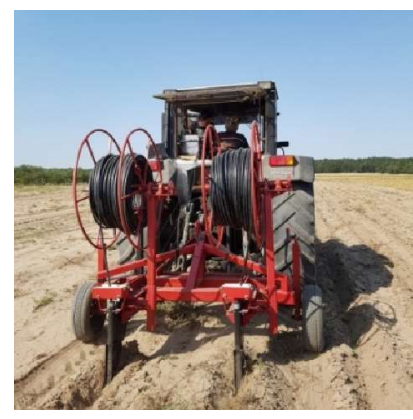

traction force measurement

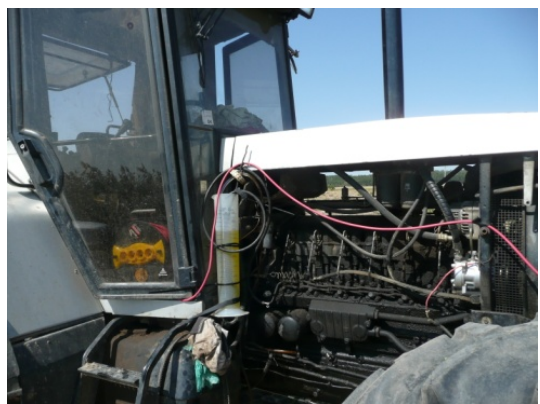

measuring the amount of fuel consumed during a test

Fig. 5. Aspects during the determination of the energy indices of the technical equipment for burying drip irrigation lines in the ground, in the experimental plot from SCDCPN Dăbuleni

The working speed was determined by timing the time required to cover the length of the test plot and reporting the space to time, using for measurement roulette, stopwatch and milestones. The slippage of the tractor was determined by recording the number of rotations of the drive wheels when idling and when driving, by traversing the length of the polygon. Hourly fuel consumption was determined by measuring with a graduated cylinder the amount of fuel consumed over the length of the test plot and reporting the amount of fuel consumed in time.

For the calculation of the values of the energy indices, the formulas presented in table 1 were used.

Table 1. Calculation formulas for energy indices.

\begin{tabular}{|c|c|c|}
\hline Index name, symbol & Calculation formulas & Significance of variables \\
\hline Working speed, $v_{l}$ & $v_{l}=\frac{3.6 \cdot \mathrm{s}}{t}, \mathrm{~km} / \mathrm{h}$ & $\begin{array}{l}s \text { - linear space travelled, in } \mathrm{m} ; \\
t \text { - space travel time, in s. }\end{array}$ \\
\hline Skating of tractor wheels, $\delta$ & $\delta=\frac{n_{s}-n_{g}}{n_{s}} 100, \%$ & $\begin{array}{l}n_{s} \text { - the number of revolutions of the drive } \\
\text { wheel under load; } \\
n_{g} \text { - the number of idle wheel rotations. }\end{array}$ \\
\hline Traction power, $P_{t r}$ & $P_{t r}=\frac{F_{t r} \cdot v_{l}}{270}, \mathrm{CP}$ & $\begin{array}{l}F_{t r}-\text { traction force measured by the } \\
\text { tensometric method, in daN; } \\
v_{l} \text { - working speed, in } \mathrm{km} / \mathrm{h} \text {. }\end{array}$ \\
\hline Hourly work capacity, $W_{e f}$ & $\begin{array}{l}\mathbf{W}_{e f}=\mathbf{0 . 1} \cdot \boldsymbol{B}_{\boldsymbol{l}} \cdot \boldsymbol{v}_{\boldsymbol{l}}, \\
\mathrm{ha} / \mathrm{h}\end{array}$ & $\begin{array}{l}B_{l} \text { - working width of the technical } \\
\text { equipment, in m; } \\
v_{l}-\text { working speed, in } \mathrm{km} / \mathrm{h} .\end{array}$ \\
\hline $\begin{array}{l}\text { Hourly fuel consumption, } \\
q\end{array}$ & $q=\frac{3.6 \cdot V}{t}, 1 / \mathrm{h}$ & $\begin{array}{l}V \text { - the volume of fuel measured with the } \\
\text { graduated cylinder, in } \mathrm{cm}^{3} \text {. }\end{array}$ \\
\hline $\begin{array}{l}\text { Fuel consumption per } \\
\text { hectare, } Q\end{array}$ & $\boldsymbol{Q}=\frac{q}{w_{e f}}, 1 / \mathrm{ha}$ & $\begin{array}{l}q \text { - hourly fuel consumption; } \\
W_{e f} \text { - hourly work capacity. }\end{array}$ \\
\hline
\end{tabular}


The precise location of the subsurface irrigation lines was made with the help of the Matrix 430 agricultural GPS made by the TeeJet company, located in the tractor cab. The major advantage of using GPS technology is that the distance between the subsurface drip lines, at two successive passes, is kept constant.

\section{Results}

The results obtained for the traction force, for the working depths $20 \mathrm{~cm}$ and $40 \mathrm{~cm}$ and the travel speeds $2.46 \mathrm{~km} / \mathrm{h}, 3.30 \mathrm{~km} / \mathrm{h}$ and $4.50 \mathrm{~km} / \mathrm{h}$, following the processing of the experimental data are presented graphically in Figure 6.
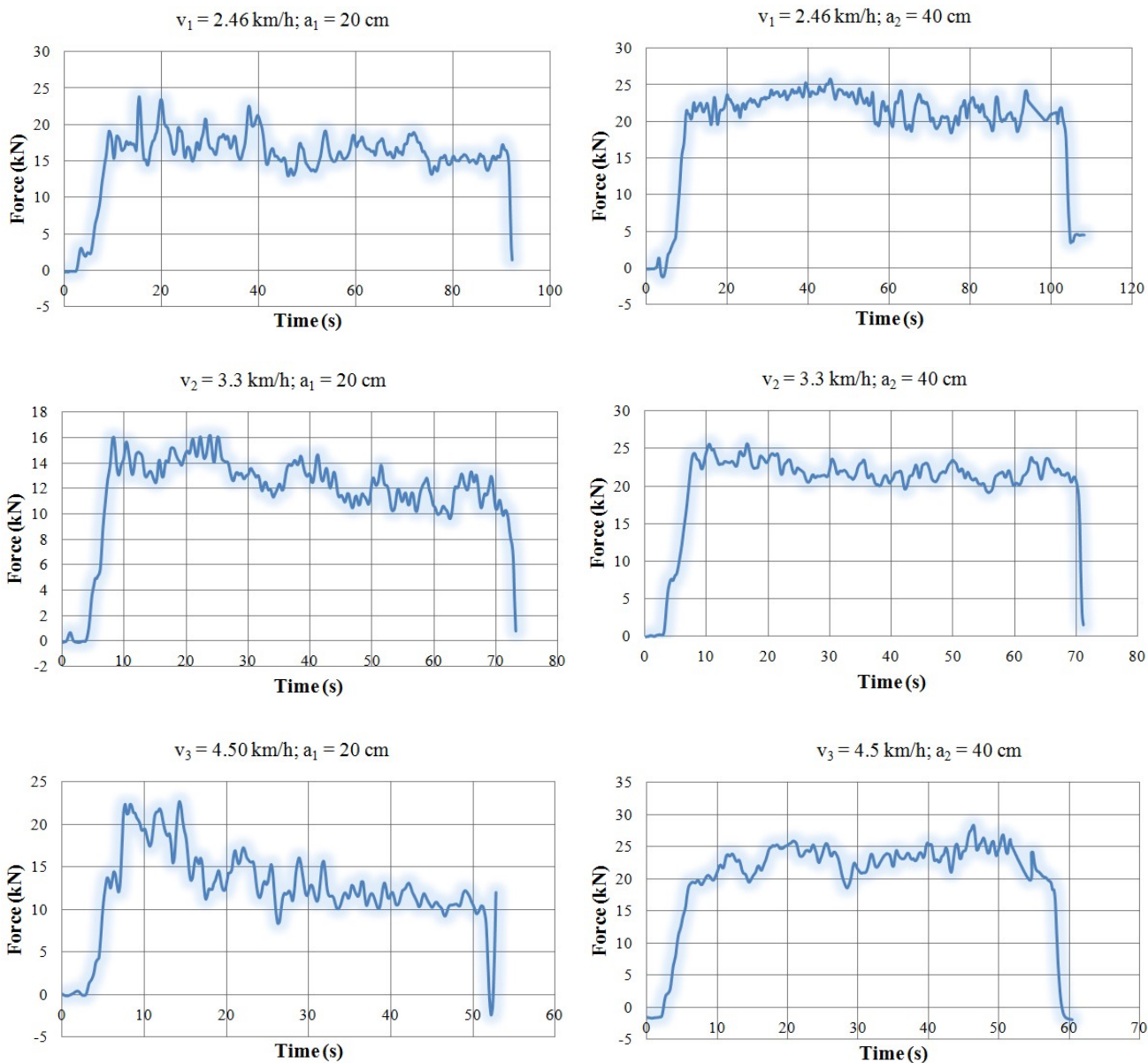

Fig. 6. Graphs of traction force variation

Analyzing the graphs in Figure 6, the average values of the traction forces were determined, which are presented centrally in table 2 .

Table 2. Average values of traction force.

\begin{tabular}{|c|c|c|c|}
\hline \multirow{3}{*}{ Working depth (cm) } & \multicolumn{3}{|c|}{ Working speed (km/h) } \\
\cline { 2 - 4 } & $\mathbf{3 . 4 6}$ & $\mathbf{3 . 3 0}$ & $\mathbf{4 . 5 0}$ \\
\cline { 2 - 4 } & \multicolumn{3}{|c|}{ Traction force (kN) } \\
\hline 20 & 16.66 & 12.92 & 13.53 \\
\hline 40 & 22.15 & 22.21 & 23.29 \\
\hline
\end{tabular}


The results obtained for energy indices, by applying the calculation formulas from chapter 2, are presented in tables 3 and 4 .

Table 3. The values of the energy indices, for the working depth $20 \mathrm{~cm}$.

\begin{tabular}{|c|c|c|c|c|c|c|}
\hline $\begin{array}{c}\text { Working } \\
\text { speed } \\
\mathbf{( k m / h )}\end{array}$ & $\begin{array}{c}\text { Skating } \\
\text { of } \\
\text { tractor } \\
\text { wheels } \\
\mathbf{( \% )}\end{array}$ & $\begin{array}{c}\text { Traction } \\
\text { force } \\
\mathbf{( d a N )}\end{array}$ & $\begin{array}{c}\text { Traction } \\
\text { power } \\
\mathbf{( C P )}\end{array}$ & $\begin{array}{c}\text { Hourly work } \\
\text { capacity } \\
\mathbf{( h a / h )}\end{array}$ & $\begin{array}{c}\text { Hourly fuel } \\
\text { consumption } \\
\mathbf{( 1 / h )}\end{array}$ & $\begin{array}{c}\text { Fuel } \\
\text { consumption } \\
\text { per hectare } \\
\mathbf{( 1 / h a )}\end{array}$ \\
\hline 2.46 & 5.0 & 1666 & 15.17 & 0.24 & 9.59 & 39.95 \\
\hline 3.30 & 6.4 & 1292 & 15.79 & 0.33 & 7.90 & 23.93 \\
\hline 4.50 & 7.1 & 1353 & 22.55 & 0.45 & 6,00 & 13.33 \\
\hline
\end{tabular}

Table 4. The values of the energy indices, for the working depth $40 \mathrm{~cm}$.

\begin{tabular}{|c|c|c|c|c|c|c|}
\hline $\begin{array}{c}\text { Working } \\
\text { speed } \\
(\mathbf{k m} / \mathbf{h})\end{array}$ & $\begin{array}{c}\text { Skating } \\
\text { of } \\
\text { tractor } \\
\text { wheels } \\
(\%)\end{array}$ & $\begin{array}{c}\text { Traction } \\
\text { force } \\
\text { (daN) }\end{array}$ & $\begin{array}{c}\text { Traction } \\
\text { power } \\
\text { (CP) }\end{array}$ & $\begin{array}{l}\text { Hourly work } \\
\text { capacity } \\
(\text { ha } / \text { h) }\end{array}$ & $\begin{array}{c}\text { Hourly fuel } \\
\text { consumption } \\
\text { (l/h) }\end{array}$ & $\begin{array}{c}\text { Fuel } \\
\text { consumption } \\
\text { per hectare } \\
\text { (l/ha) }\end{array}$ \\
\hline 2.46 & 9,5 & 2215 & 20.18 & 0.24 & 9.73 & 40.54 \\
\hline 3.30 & 9,7 & 2221 & 27.14 & 0.33 & 9.00 & 27.20 \\
\hline 4.50 & 10,2 & 2329 & 38.81 & 0.45 & 8.36 & 18.57 \\
\hline
\end{tabular}

Analyzing the values in tables 3 and 4 for traction power, it is found that the required power is clearly lower than the power that the used tractor can develop (150 HP). For example, for a working depth of $40 \mathrm{~cm}$ and a working speed of $4.5 \mathrm{~km} / \mathrm{h}$, a traction power of $38.81 \mathrm{hp}$ was obtained. The evolution of the hourly fuel consumption is inscribed on the tractor consumption curve, but without presenting significant differences depending on the working speed.

\section{Conclusions}

The experiments with the technical equipment for burying drip irrigation lines in the ground have led to the conclusion that it can be used successfully in the technology of subsurface crop irrigation.

Considering the necessary power determined during the experiments, we can strongly state that the equipment can also be used in aggregate with a tractor with a power of less than 150 HP, $100 \mathrm{HP}$ being recommended.

Future research directions will focus on determining the degree of wear of working organs in the conditions of sandy soils in the Dabuleni area and on determining the coefficients of use of working time. Also, higher working speeds must be taken into account, given the very good behaviour of the equipment during the tests performed, in order to increase productivity.

This work was supported by a grant of the Romanian Ministry of Research and Innovation CCDI - UEFISCDI, Project INNOVATIVE TECHNOLOGIES FOR IRRIGATION OF AGRICULTURAL CROPS IN ARID, SEMIARID AND SUBHUMID-DRY CLIMATE, project number PN-III-P1-1.2PCCDI-2017-0254, contract no. 27PCCDI / 2018.

\section{References}

1. C. R. Schultz, M. S. Tollefson, H. A.Wuertz, US Patent 4447173 (1984)

2. https://www.rainfloirrigation.com/equipment/drip-applicators

3. http://www.buctraco.com/3\%20Online $\% 20$ Catalog/DripIrrigation.htm 
4. https://andros-eng.com/irrigation/boss-installation-implements/

5. E.D.Vories, P.L. Tacker, S.W. Lancaster, R.E. Glover, Agricultural Water Management 96:6, 912-916 (2009)

6. S. J. van Donk, J. L. Petersen, D. R. Davison, Irrig Sci 31:599-609 (2013)

7. C. Murley, S. Sharma, J. Warren, B. Arnall, W. Raun, Agricultural Water Management 208, 357-362 (2018)

8. S. Evett, G. Marek, P. Colaizzi, D. Brauer, S. O'Shaughnessy, Transactions of the ASABE 62, 1377-1393 (2019)

9. N. Patel, T Rajput, Agric. Water Manag. 88, 209-223 (2007)

10. V.K. Tripathi, T.B.S. Rajput, N. Patel, J. Clean. Prod. 139, 396-406 (2016)

11. M. Dorta-Santos, M. Tejedor, C. Jiménez, J.M. Hernández-Moreno, M. Palacios-Díaz, F.J. Diaz, Ecol. Eng. 79, 60-68 (2015) 